Editorial

\title{
Surface Aspects of Semiconductor Photochemistry
}

\author{
Maria Vittoria Dozzi *(i) and Elena Selli (D) \\ Dipartimento di Chimica, Università degli Studi di Milano, via Golgi 19, I-20133 Milano, Italy; \\ elena.selli@unimi.it \\ * Correspondence: mariavittoria.dozzi@unimi.it
}

Received: 7 July 2020; Accepted: 19 August 2020; Published: 2 September 2020

The Surfaces Special Issue entitled "Surface Aspects of Semiconductor Photochemistry" is mainly devoted to the 7th International Conference on Semiconductor Photochemistry (SP7), which was held on 11-14 September 2019 in Milano, Italy, in the beautiful Renaissance " $\mathrm{Ca}^{\prime}$ Granda" main building of the University Milan. The conference saw the active participation of more than 160 attendants in an intense program, including 12 plenary and keynote lectures, 60 oral presentations, 20 flash presentations by young authors and 2 poster sessions.

This Special Issue, collecting 6 original contributions and one literature review, well highlights the main aim of the SP7 conference to cover the current developments in the area of semiconductor photochemistry and photo(electro)catalysis, focusing specific attention on either new findings related to "historical" $\mathrm{TiO}_{2}$-based materials or to up-to-date results obtained with emerging and promising semiconductor photo(electro)catalytic materials.

Nowadays heterogeneous photo(electro)catalysis with semiconductors plays a central role in facing new global environment- and energy-related issues [1]. In fact, besides in the catalysis of light-driven transformations of organic compounds [2], this research field is widely investigated as a useful technique not only for the photo-induced degradation of contaminants in waste waters and in air [3-5], but also for promoting the solar into chemical energy conversion through thermodynamically up-hill reactions producing fuels, such as hydrogen evolution from water [6-9] and $\mathrm{CO}_{2}$ photo-reduction to methane and methanol [10-12]. Intense research efforts in the field date back to the early 1970s, when Fujishima and Honda discovered the photoassisted splitting of water on $\mathrm{TiO}_{2}$ electrodes [13].

All photocatalytic processes are initiated by excitation of a semiconductor photocatalyst by photons of energy higher than the semiconductor band gap. This results in the formation of electron-hole pairs, from which a great variety of environmentally friendly redox transformations may occur involving chemical species with suitable redox potentials, adsorbed on the photocatalyst surface [14].

Among different semiconductor photocatalysts [15-17], $\mathrm{TiO}_{2}$ is still the most investigated and employed one, due to its high oxidation ability, chemical and biological inertness, photostability and cheapness. However, its overall photocatalytic efficiency is limited by its intrinsic high energy band gap ( $3.2 \mathrm{eV}$ for the anatase phase, $3.0 \mathrm{eV}$ for the rutile phase), allowing the exploitation of only a small portion $(5 \%)$ of the sunlight. Furthermore, as for all photoactive semiconductors, undesired bulk and/or surface recombination of the photogenerated electron-hole pairs easily occurs [18].

In this scenario, surface science is involved in two main aspects of the research in the field of semiconductor photochemistry. In fact, specific surface and/or bulk characterization techniques $[19,20]$, typical of materials' surface science, can be employed in order to get better insight into the potential specific correlation existing between the semiconductor surface properties and the resultant photoactivity performance of photoactive semiconductor materials, to be considered in the design of efficient and easily applicable photocatalysts [21]. At the same time, various strategies, including crystal phase tailoring and textural modification [22,23], electronic structure engineering, interfacial heterostructuring [24-28], surface sensitization and modification of semiconductor photocatalysts $[29,30]$ have been developed in the attempt to modify and possibly tune the photocatalytic 
processes involving light harvesting and semiconductor excitation, in relation to bulk diffusion, surface trapping and interfacial transfer of the electrons and holes photoproduced on the semiconductor surface upon irradiation [22,31-33].

In this context, within this special issue Vorontsov et al. [34] provide an overview on recent findings concerning the peculiar role played by the surface chemistry of anatase $\mathrm{TiO}_{2}$ on both photocatalytic and photo(electro)catalytic processes. Particular attention is focused on the use of the semiconductor crystal facets engineering as an important and powerful strategy to properly tune and optimize both the physico-chemical properties and the substrate- and reaction-sensitive activity of the photocatalysts [35-37]. Therefore, as no unambiguous conclusion has been yet drawn about either the photoactivity order of clean anatase crystal facets, or their optimal balance to maximize photoactivity, general understanding needs to be developed, together with prediction methods, to properly select shaped-controlled $\mathrm{TiO}_{2}$ materials, able to selectively promote specific photocatalytic processes.

At the same time, either metal/cation [38] or non-metal/anion [39,40] doping has been largely pursued to extend the spectral breadth and efficiency of $\mathrm{TiO}_{2}$ photoresponse. The still under debate nature and effectiveness of doping titanium dioxide with heteroatoms is testified by the huge and progressively increasing number of studies in the field. The charged carrier recombination and the interfacial electron transfer rates can be significantly altered by semiconductor doping. For instance, the photoreactivity of doped $\mathrm{TiO}_{2}$ is influenced by several parameters such as the dopant concentration, the energy levels of dopants differently located within the $\mathrm{TiO}_{2}$ lattice, their electronic configuration, as well as by the irradiation intensity. Therefore, the specific preparation method is expected to have significant impact on the overall photoactivity of doped $\mathrm{TiO}_{2}$.

Among the different methods employed to obtain doped $\mathrm{TiO}_{2}$ films, in the special issue Arab et al. [41] report a systematic investigation on the optical and photoelectrochemical properties of Ni-doped $\mathrm{TiO}_{2}$ layers obtained using the quite innovative plasma electrolytic oxidation (PEO) technique, carried out in galvanostatic mode in alkaline electrolytes containing nickel acetate as $\mathrm{Ni}$ source. Compared to traditional anodizing procedures leading to the formation of $\mathrm{TiO}_{2}$ nanotube arrays, the PEO process works at higher current and higher voltage, but it requires a very short processing time (less than $10 \mathrm{~min}$ ), allowing high rates of oxide growth $\left(c a .1 \mu \mathrm{m} \mathrm{min}{ }^{-1}\right)$. Furthermore, the high pressure and temperature locally induced by sparking can significantly affect the oxide morphology, crystal structure and composition, promoting instantaneous oxide crystallization and incorporation of chemical species from the electrolyte. This confirms the wide potential application of PEO at the industrial scale not only for the synthesis of protective coatings, but also for the preparation of large area electrodes for photo(electro)catalytic water treatment [42].

Concerning non-metal doped $\mathrm{TiO}_{2}$-based photocatalysts, Chen et al. [43] succeeded in preparing photoactive nitrogen-doped $\mathrm{TiO}_{2}$ powders with controlled micro/macroporous multi-scale structure by adopting a microphase separation method. In particular, these authors systematically investigated the key role played by the addition of citric acid, instead of any other hard or soft templating agent, to obtain a stable macroporous framework, able to positively contribute to the photoactivity of the resultant $\mathrm{TiO}_{2}$, mainly due to enhanced light absorption efficiency.

Regarding industrial applications of photocatalysis, Bianchi et al. [44] report on the use of a digital printing process for the preparation of functionalized industrial porcelain-grès tiles, working as self-cleaning photocatalytic building materials. By the employed economic and fast procedure, a homogeneous distribution of micro-sized $\mathrm{TiO}_{2}$ materials surface decorated with $\mathrm{Ag}$ nanoparticles can be obtained, with excellent photocatalytic antimicrobial activity on Gram-negative pathogenic bacteria such as E. coli, under both indoor and outdoor irradiation. A mechanism involving the efficient photocatalytic production of reactive oxygen species due to enhanced charge carrier separation in $\mathrm{Ag}-\mathrm{TiO}_{2}$ fixed powders is proposed to explain the good photocatalytic ability of such tiles with respect to standard systems containing only $\mathrm{Ag}^{+}$species.

In relation to heterogeneous photocatalysis investigations for the chemical synthesis of added-value organic compounds, the contribution of Vaiano et al. [45] deals with the preliminary study on the 
selective photocatalyzed cyclohexane oxydehydrogenation to benzene and cyclohexene products in the presence of $\mathrm{MoO}_{\mathrm{x}}$-functionalized ferrierite zeolites in a gas-solid continuous flow reactor under UV irradiation. A possible mechanism initiated by the photoactivation of polymolybdate species for the selective conversion of cyclohexane is proposed, which sheds light on the peculiar role played by the interaction between the zeolite and the molybdenum oxide species in modifying the catalyst selectivity.

Focusing attention on new promising semiconductor photocatalysts able to maximize the exploitation of visible light to promote water oxidation, $\mathrm{BiVO}_{4}$, with its relatively narrow bandgap of $2.4 \mathrm{eV}$, emerged thanks to its visible light absorption properties, its stability over a wide $\mathrm{pH}$ range and valence band edge position suitable for water oxidation. In spite of these attractive features, $\mathrm{BiVO}_{4}$ photoanodes suffer from low majority carrier mobility, limited charge separation and relatively poor water oxidation kinetics [46]. In this regard, Pedroni et al. [47] confirmed that the combination of $\mathrm{BiVO}_{4}$ with $\mathrm{WO}_{3}$ in a heterojunction system fabricated by means of reactive radio frequency plasma (co)sputtering may lead to improved charge separation. The so obtained coupled system, properly optimized in relation to both the $\mathrm{WO}_{3}$ bilayer thickness and the adopted post calcination temperature, can efficiently exploit the visible-light photoactivity of $\mathrm{BiVO}_{4}$ together with the intrinsic efficient charge transport properties of the $\mathrm{WO}_{3}$ semiconductor, with an overall significant synergistic increase of the photoelectrochemical performance under solar light irradiation. By means of incident photon to current efficiency measurements, the authors support previously reported findings unveiling the wavelength-dependent charge carrier interactions occurring at the interface between the two oxides [48-50]. In particular, while under selective $\mathrm{BiVO}_{4}$ excitation (at wavelength above $450 \mathrm{~nm}$ ) the electrons photoexcited in $\mathrm{BiVO}_{4}$ conduction band are efficiently injected into $\mathrm{WO}_{3}$, upon the excitation of both semiconductors (at wavelength below $450 \mathrm{~nm}$ ) a detrimental recombination channel opens at the interface, between the electrons photo-promoted in the $\mathrm{WO}_{3}$ conduction band and the holes photo-produced in the $\mathrm{BiVO}_{4}$ valence band, which results in a decrease of the overall photoelectrochemical performance of the coupled system.

The Special Issue is completed by the contribution of Polo et al. [51], presenting a systematic study on the effects induced by post-synthesis hydrogenation on the photoelectrochemical performances of zinc ferrite $\left(\mathrm{ZnFe}_{2} \mathrm{O}_{4}\right)$ flat films photoanodes for water oxidation as a function of the pre-annealing temperature adopted in their synthesis. In fact, zinc ferrite has been recently explored as a binary oxide alternative to the much more investigated $\mathrm{Fe}_{2} \mathrm{O}_{3}$, especially thanks to its remarkable thermal and chemical stability together with a relatively narrow energy band gap of $c a .2 .0 \mathrm{eV}[52,53]$. However, the performance of $\mathrm{ZnFe}_{2} \mathrm{O}_{4}$ is mainly limited by an inefficient charge separation in the bulk with respect to the hole transport towards the film/electrolyte interface. In this regard, a reductive treatment under $\mathrm{H}_{2}$ atmosphere was carried out under mild heating conditions with the main aim of improving the electron conductivity of the films through the introduction of oxygen vacancies acting as n-type dopants. Interestingly, the investigation was focused on flat zinc ferrite films with moderate thickness, i.e., $c a .100 \mathrm{~nm}$ thick, prepared according to a generalized approach for ternary metal oxides, which offers an easily processable green route to obtain optically transparent films suitable to be employed as photoanodes in dual absorber tandem photoelectrochemical cells [54]. In relation with previous findings [55], Polo et al. demonstrate how specific structural and/or surface properties, together with the initial film morphology, differently affect the overall contribution of post-synthesis hydrogenation to the efficiency of zinc ferrite-based photoanodes.

We are confident that this Special Issue will help the reader to get a concise but updated view concerning efforts and advances recently made toward a better understanding of the multiple surface aspects governing the continuously evolving field of semiconductor photochemistry.

Funding: This research received no external funding.

Acknowledgments: Guest Editors would like to thank all Authors and Reviewers of this Special Issue for their valuable contributions.

Conflicts of Interest: The authors declare no conflict of interest. 


\section{References}

1. Osterloh, F.E. Photocatalysis versus Photosynthesis: A Sensitivity Analysis of Devices for Solar Energy Conversion and Chemical Transformations. ACS Energy Lett. 2017, 2, 445-453. [CrossRef]

2. Riente, P.; Noël, T. Application of metal oxide semiconductors in light-driven organic transformations. Catal. Sci. Technol. 2019, 9, 5186-5232. [CrossRef]

3. Ke, J.; Adnan Younis, M.; Kong, Y.; Zhou, H.; Liu, J.; Lei, L.; Hou, Y. Nanostructured Ternary Metal Tungstate-Based Photocatalysts for Environmental Purification and Solar Water Splitting: A Review. Nano-Micro Lett. 2018, 10, 1-27. [CrossRef] [PubMed]

4. Park, H.; Park, Y.; Kim, W.; Choi, W. Surface modification of $\mathrm{TiO}_{2}$ photocatalyst for environmental applications. J. Photochem. Photobiol. C Photochem. Rev. 2013, 15, 1-20. [CrossRef]

5. Chiu, Y.H.; Chang, T.F.M.; Chen, C.Y.; Sone, M.; Hsu, Y.J. Mechanistic insights into photodegradation of organic dyes using heterostructure photocatalysts. Catalysts 2019, 9. [CrossRef]

6. Wang, Z.; Li, C.; Domen, K. Recent developments in heterogeneous photocatalysts for solar-driven overall water splitting. Chem. Soc. Rev. 2019, 48, 2109-2125. [CrossRef]

7. Cai, J.; Shen, J.; Zhang, X.; Ng, Y.H.; Huang, J.; Guo, W.; Lin, C.; Lai, Y. Light-Driven Sustainable Hydrogen Production Utilizing $\mathrm{TiO}_{2}$ Nanostructures: A Review. Small Methods 2019, 3, 1-24. [CrossRef]

8. Pellegrino, F.; Sordello, F.; Minella, M.; Minero, C.; Maurino, V. The Role of Surface Texture on the Photocatalytic $\mathrm{H}_{2}$ Production on $\mathrm{TiO}_{2}$. Catalysts 2019, 9, 32. [CrossRef]

9. Wang, Y.; Suzuki, H.; Xie, J.; Tomita, O.; Martin, D.J.; Higashi, M.; Kong, D.; Abe, R.; Tang, J. Mimicking Natural Photosynthesis: Solar to Renewable $\mathrm{H}_{2}$ Fuel Synthesis by Z-Scheme Water Splitting Systems. Chem. Rev. 2018, 118, 5201-5241. [CrossRef]

10. Chang, X.; Wang, T.; Gong, J. $\mathrm{CO}_{2}$ photo-reduction: Insights into $\mathrm{CO}_{2}$ activation and reaction on surfaces of photocatalysts. Energy Environ. Sci. 2016, 9, 2177-2196. [CrossRef]

11. Prabhu, P.; Jose, V.; Lee, J.M. Heterostructured Catalysts for Electrocatalytic and Photocatalytic Carbon Dioxide Reduction. Adv. Funct. Mater. 2020, 30, 1-32. [CrossRef]

12. $\mathrm{Xu}, \mathrm{S}$.; Carter, E.A. Theoretical Insights into Heterogeneous (Photo)electrochemical $\mathrm{CO}_{2}$ Reduction. Chem. Rev. 2019, 119, 6631-6669. [CrossRef] [PubMed]

13. Fujishima, A.; Honda, K. Electrochemical Photolysis of Water at a Semiconductor Electrode. Nature 1972, 238, 37-38. [CrossRef] [PubMed]

14. Yang, X.; Wang, D. Photocatalysis: From Fundamental Principles to Materials and Applications. ACS Appl. Energy Mater. 2018, 1, 6657-6693. [CrossRef]

15. Sivula, K.; Van De Krol, R. Semiconducting materials for photoelectrochemical energy conversion. Nat. Rev. Mater. 2016, 1. [CrossRef]

16. Lee, D.K.; Lee, D.; Lumley, M.A.; Choi, K.S. Progress on ternary oxide-based photoanodes for use in photoelectrochemical cells for solar water splitting. Chem. Soc. Rev. 2019, 48, 2126-2157. [CrossRef]

17. Lianos, P. Review of recent trends in photoelectrocatalytic conversion of solar energy to electricity and hydrogen. Appl. Catal. B Environ. 2017, 210, 235-254. [CrossRef]

18. Schneider, J.; Matsuoka, M.; Takeuchi, M.; Zhang, J.; Horiuchi, Y.; Anpo, M.; Bahnemann, D.W. Understanding $\mathrm{TiO}_{2}$ Photocatalysis: Mechanisms and Materials. Chem. Rev. 2014, 114, 9919-9986. [CrossRef]

19. Luo, C.; Ren, X.; Dai, Z.; Zhang, Y.; Qi, X.; Pan, C. Present Perspectives of Advanced Characterization Techniques in $\mathrm{TiO}_{2}$-Based Photocatalysts. ACS Appl. Mater. Interfaces 2017, 9, 23265-23286. [CrossRef]

20. Zhang, L.; Ran, J.; Qiao, S.Z.; Jaroniec, M. Characterization of semiconductor photocatalysts. Chem. Soc. Rev. 2019, 48, 5184-5206. [CrossRef]

21. Guo, Q.; Zhou, C.; Ma, Z.; Yang, X. Fundamentals of $\mathrm{TiO}_{2}$ Photocatalysis: Concepts, Mechanisms, and Challenges. Adv. Mater. 2019, 31, 1-26. [CrossRef] [PubMed]

22. Bai, S.; Wang, L.; Li, Z.; Xiong, Y. Facet-Engineered Surface and Interface Design of Photocatalytic Materials. Adv. Sci. 2017, 4. [CrossRef] [PubMed]

23. Wang, K.; Janczarek, M.; Wei, Z.; Raja-Mogan, T.; Endo-Kimura, M.; Khedr, T.M.; Ohtani, B.; Kowalska, E. Morphology-and crystalline composition-governed activity of titania-based photocatalysts: Overview and perspective. Catalysts 2019, 9. [CrossRef]

24. Moniz, S.J.A.; Shevlin, S.A.; Martin, D.J.; Guo, Z.X.; Tang, J. Visible-light driven heterojunction photocatalysts for water splitting-a critical review. Energy Environ. Sci. 2015, 8, 731-759. [CrossRef] 
25. Afroz, K.; Moniruddin, M.; Bakranov, N.; Kudaibergenov, S.; Nuraje, N. A heterojunction strategy to improve the visible light sensitive water splitting performance of photocatalytic materials. J. Mater. Chem. A 2018, 6, 21696-21718. [CrossRef]

26. Zhang, L.; Jaroniec, M. Toward designing semiconductor-semiconductor heterojunctions for photocatalytic applications. Appl. Surf. Sci. 2018, 430, 2-17. [CrossRef]

27. Wei, L.; Yu, C.; Zhang, Q.; Liu, H.; Wang, Y. TiO 2 -based heterojunction photocatalysts for photocatalytic reduction of $\mathrm{CO}_{2}$ into solar fuels. J. Mater. Chem. A 2018, 6, 22411-22436. [CrossRef]

28. Bera, S.; Won, D.I.; Rawal, S.B.; Kang, H.J.; Lee, W.I. Design of visible-light photocatalysts by coupling of inorganic semiconductors. Catal. Today 2019, 335, 3-19. [CrossRef]

29. Guijarro, N.; Prévot, M.S.; Sivula, K. Surface modification of semiconductor photoelectrodes. Phys. Chem. Chem. Phys. 2015, 17, 15655-15674. [CrossRef]

30. Kumar, S.G.; Rao, K.S.R.K. Comparison of modification strategies towards enhanced charge carrier separation and photocatalytic degradation activity of metal oxide semiconductors $\left(\mathrm{TiO}_{2}, \mathrm{WO}_{3}\right.$ and $\left.\mathrm{ZnO}\right)$. Appl. Surf. Sci. 2017, 391, 124-148. [CrossRef]

31. Yang, W.; Prabhakar, R.R.; Tan, J.; Tilley, S.D.; Moon, J. Strategies for enhancing the photocurrent, photovoltage, and stability of photoelectrodes for photoelectrochemical water splitting. Chem. Soc. Rev. 2019, 48, 4979-5015. [CrossRef] [PubMed]

32. Jiang, C.; Moniz, S.J.A.; Wang, A.; Zhang, T.; Tang, J. Photoelectrochemical devices for solar water splitting-materials and challenges. Chem. Soc. Rev. 2017, 46, 4645-4660. [CrossRef] [PubMed]

33. Xiao, M.; Luo, B.; Wang, Z.; Wang, S.; Wang, L. Recent Advances of Metal-Oxide Photoanodes: Engineering of Charge Separation and Transportation toward Efficient Solar Water Splitting. Sol. RRL 2020, 1900509, 1900509. [CrossRef]

34. Vorontsov, A.V.; Valdés, H.; Smirniotis, P.G.; Paz, Y. Recent Advancements in the Understanding of the Surface Chemistry in $\mathrm{TiO}_{2}$ Photocatalysis. Surfaces 2020, 3, 72-92. [CrossRef]

35. Dozzi, M.; Selli, E. Specific Facets-Dominated Anatase $\mathrm{TiO}_{2}$ : Fluorine-Mediated Synthesis and Photoactivity. Catalysts 2013, 3, 455-485. [CrossRef]

36. Maisano, M.; Dozzi, M.V.; Selli, E. Searching for facet-dependent photoactivity of shape-controlled anatase $\mathrm{TiO}_{2}$. J. Photochem. Photobiol. C Photochem. Rev. 2016, 28, 29-43. [CrossRef]

37. Wang, S.; Liu, G.; Wang, L. Crystal Facet Engineering of Photoelectrodes for Photoelectrochemical Water Splitting. Chem. Rev. 2019, 119, 5192-5247. [CrossRef]

38. Kumaravel, V.; Mathew, S.; Bartlett, J.; Pillai, S.C. Photocatalytic hydrogen production using metal doped $\mathrm{TiO}_{2}$ : A review of recent advances. Appl. Catal. B Environ. 2019, 244, 1021-1064. [CrossRef]

39. Devi, L.G.; Kavitha, R. A review on non metal ion doped titania for the photocatalytic degradation of organic pollutants under UV/solar light: Role of photogenerated charge carrier dynamics in enhancing the activity. Appl. Catal. B Environ. 2013, 140-141, 559-587. [CrossRef]

40. Dozzi, M.V.; Selli, E. Doping $\mathrm{TiO}_{2}$ with p-block elements: Effects on photocatalytic activity. J. Photochem. Photobiol. C Photochem. Rev. 2013, 14, 13-28. [CrossRef]

41. Arab, H.; Chiarello, G.L.; Selli, E.; Bomboi, G.; Calloni, A.; Bussetti, G.; Albani, G.; Bestetti, M.; Franz, S. Ni-Doped Titanium Dioxide Films Obtained by Plasma Electrolytic Oxidation in Refrigerated Electrolytes. Surfaces 2020, 3, 168-181. [CrossRef]

42. Franz, S.; Arab, H.; Chiarello, G.L.; Bestetti, M.; Selli, E. Single-Step Preparation of Large Area TiO Photoelectrodes for Water Splitting. Adv. Energy Mater. 2020, 10, 1-11. [CrossRef]

43. Chen, R.; Shao, N.; Zhou, X.; Chen, T. Citric Acid Regulated Fabrication of Macroporous $\mathrm{TiO}_{2}$. Surfaces 2020, 3, 50-60. [CrossRef]

44. Bianchi, C.L.; Cerrato, G.; Bresolin, B.M.; Djellabi, R.; Rtimi, S. Digitally Printed AgNPs Doped $\mathrm{TiO}_{2}$ on Commercial Porcelain-Grès Tiles: Synergistic Effects and Continuous Photocatalytic Antibacterial Activity. Surfaces 2020, 3, 11-25. [CrossRef]

45. Vaiano, V.; Sannino, D. UV Light Driven Selective Oxidation of Cyclohexane in Gaseous Phase Using Mo-Functionalized Zeolites. Surfaces 2019, 2, 546-559. [CrossRef]

46. Park, Y.; McDonald, K.J.; Choi, K.-S. Progress in bismuth vanadate photoanodes for use in solar water oxidation. Chem. Soc. Rev. 2013, 42, 2321-2337. [CrossRef]

47. Pedroni, M.; Chiarello, G.L.; Vassallo, E.; Selli, E. Multilayer $\mathrm{WO}_{3} / \mathrm{BiVO}_{4}$ Photoanodes for Solar-Driven Water Splitting Prepared by RF-Plasma Sputtering. Surfaces 2020, 3, 105-115. [CrossRef] 
48. Grigioni, I.; Stamplecoskie, K.G.; Jara, D.H.; Dozzi, M.V.; Oriana, A.; Cerullo, G.; Kamat, P.V.; Selli, E. Wavelength-Dependent Ultrafast Charge Carrier Separation in the $\mathrm{WO}_{3} / \mathrm{BiVO}_{4}$ Coupled System. ACS Energy Lett. 2017, 2, 1362-1367. [CrossRef]

49. Grigioni, I.; Abdellah, M.; Corti, A.; Dozzi, M.V.; Hammarström, L.; Selli, E. Photoinduced Charge-Transfer Dynamics in $\mathrm{WO}_{3} / \mathrm{BiVO}_{4}$ Photoanodes Probed through Midinfrared Transient Absorption Spectroscopy. J. Am. Chem. Soc. 2018, 140, 14042-14045. [CrossRef]

50. Grigioni, I.; Dozzi, M.V.; Selli, E. Photoinduced electron transfer in $\mathrm{WO}_{3} / \mathrm{BiVO}_{4}$ heterojunction photoanodes: Effects of the $\mathrm{WO}_{3}$ layer thickness. J. Phys. Condens. Matter 2020, 32, 014001. [CrossRef]

51. Polo, A.; Lhermitte, C.R.; Dozzi, M.V.; Selli, E.; Sivula, K. Hydrogenation of $\mathrm{ZnFe}_{2} \mathrm{O}_{4}$ Flat Films: Effects of the Pre-Annealing Temperature on the Photoanodes Efficiency for Water Oxidation. Surfaces 2020, 3, 93-104. [CrossRef]

52. Guijarro, N.; Bornoz, P.; Prévot, M.; Yu, X.; Zhu, X.; Johnson, M.; Jeanbourquin, X.; Le Formal, F.; Sivula, K. Evaluating spinel ferrites $\mathrm{MFe}_{2} \mathrm{O}_{4}(\mathrm{M}=\mathrm{Cu}, \mathrm{Mg}, \mathrm{Zn})$ as photoanodes for solar water oxidation: Prospects and limitations. Sustain. Energy Fuels 2018, 2, 103-117. [CrossRef]

53. Zhu, X.; Guijarro, N.; Liu, Y.; Schouwink, P.; Wells, R.A.; Le Formal, F.; Sun, S.; Gao, C.; Sivula, K. Spinel structural disorder influences solar-water-splitting performance of $\mathrm{ZnFe}_{2} \mathrm{O}_{4}$ nanorod photoanodes. Adv. Mater. 2018, 30, 1-6. [CrossRef] [PubMed]

54. Lhermitte, C.R.; Polo, A.; Yao, L.; Boudoire, F.A.; Guijarro, N.; Sivula, K. Generalized Synthesis to Produce Transparent Thin Films of Ternary Metal Oxide Photoelectrodes. ChemSusChem 2020. [CrossRef]

55. Kim, J.H.; Jang, Y.J.; Kim, J.H.; Jang, J.W.; Choi, S.H.; Lee, J.S. Defective $\mathrm{ZnFe}_{2} \mathrm{O}_{4}$ nanorods with oxygen vacancy for photoelectrochemical water splitting. Nanoscale 2015, 7, 19144-19151. [CrossRef]

(C) 2020 by the authors. Licensee MDPI, Basel, Switzerland. This article is an open access article distributed under the terms and conditions of the Creative Commons Attribution (CC BY) license (http://creativecommons.org/licenses/by/4.0/). 